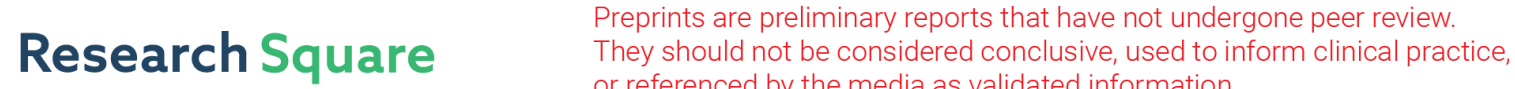 or referenced by the media as validated information. \\ Too Much of a Good Thing? Inorganic Nitrogen $(\mathrm{N})$ Inhibits Moss-Associated $\mathrm{N}_{2}$ Fixation But Organic $\mathbf{N}$ Can Promote It
}

\section{Yinliu Wang}

University of Copenhagen: Kobenhavns Universitet

Signe Lett

University of Copenhagen: Kobenhavns Universitet

Kathrin Rousk ( $\boldsymbol{\nabla}$ kathrin.rousk@bio.ku.dk)

University of Copenhagen: Kobenhavns Universitet https://orcid.org/0000-0003-3140-9864

\section{Research Article}

Keywords: Cyanobacteria, Feathermosses, Nitrogen deposition, Nitrogen fixation, Organic nitrogen, Sphagnum

Posted Date: November 8th, 2021

DOI: https://doi.org/10.21203/rs.3.rs-1022519/v1

License: (c) (i) This work is licensed under a Creative Commons Attribution 4.0 International License.

Read Full License

Version of Record: A version of this preprint was published at Biogeochemistry on April 1st, 2022. See the published version at https://doi.org/10.1007/s10533-022-00920-0. 


\section{Abstract}

Moss-associated nitrogen $\left(\mathrm{N}_{2}\right)$ fixation is one of the main inputs of new $\mathrm{N}$ in pristine ecosystems that receive low amounts of atmospheric $N$ deposition. Previous studies have shown that $\mathrm{N}_{2}$ fixation is inhibited by inorganic $\mathrm{N}(\mathrm{IN})$ inputs, but if $\mathrm{N}_{2}$ fixation in mosses is similarly affected by organic $\mathrm{N}(\mathrm{ON})$ remains unknown. Here, we assessed $\mathrm{N}_{2}$ fixation in two dominant mosses in boreal forests (Pleurozium schreberi and Sphagnum capillifolium) in response to different levels of $\mathrm{N}$, simulating realistic (up to $4 \mathrm{~kg}$ $\mathrm{N} \mathrm{ha}^{-1} \mathrm{yr}^{-1}$ ) and extreme $\mathrm{N}$ deposition rates in pristine ecosystems (up to $20 \mathrm{~kg} \mathrm{~N} \mathrm{ha}^{-1} \mathrm{yr}^{-1}$ ) of IN $\left(\mathrm{NH}_{4} \mathrm{NO}_{3}\right)$ and $\mathrm{ON}$ (alanine and urea). We also assessed if $\mathrm{N}_{2}$ fixation can recover from the $\mathrm{N}$ additions. In the realistic scenario, $\mathrm{N}_{2}$ fixation was inhibited by increasing $\mathrm{NH}_{4} \mathrm{NO}_{3}$ additions in $P$. schreberibut not in S. capillifolium, and alanine and urea stimulated $\mathrm{N}_{2}$ fixation in both moss species. In contrast, in the extreme $\mathrm{N}$ additions, increasing $\mathrm{N}$ inputs inhibited $\mathrm{N}_{2}$ fixation in both moss species and all $\mathrm{N}$ forms. Nitrogen fixation was more sensitive to $\mathrm{N}$ inputs in $P$. schreberi than in $S$. capillifolium and was higher in the recovery phase after the realistic compared to the extreme $\mathrm{N}$ additions. These results demonstrate that $\mathrm{N}_{2}$ fixation in mosses is less sensitive to organic than inorganic $\mathrm{N}$ inputs and highlight the importance of considering different $\mathrm{N}$ forms and species-specific responses when estimating the impact of $\mathrm{N}$ inputs on ecosystem functions such as moss-associated $\mathrm{N}_{2}$ fixation.

\section{Introduction}

Nitrogen $(\mathrm{N})$ is usually the limiting nutrient for plant productivity in pristine ecosystems such as boreal forests and arctic tundra. In these ecosystems, $\mathrm{N}_{2}$ fixation by moss-cyanobacteria associations can contribute $>2 \mathrm{~kg} \mathrm{~N} \mathrm{ha}^{-1} \mathrm{yr}^{-1}$ to new $\mathrm{N}$ input, being one of the major sources of $\mathrm{N}$ (DeLuca et al. 2002; Rousk et al. 2017). Nitrogen fixation by moss-associated bacteria (diazotrophs) has been shown to be sensitive to inorganic N inputs through N deposition (Ackermann et al. 2012; Rousk et al. 2013; Salemaa et al. 2019; Zheng et al. 2019). However, we still know little about how the projected increase in $\mathrm{N}$ input affect moss-associated $\mathrm{N}_{2}$ fixation in pristine ecosystems. More importantly, most studies on the effects of increased $\mathrm{N}$ availability or deposition have focused on inorganic $\mathrm{N}$ (e.g. ammonium), while the effects of organic $\mathrm{N}$ on $\mathrm{N}_{2}$ fixation in mosses is unknown.

Because $\mathrm{N}_{2}$ fixation is an energy costly process, $\mathrm{N}_{2}$ fixation associated with moss-cyanobacteria declines with increasing environmental $\mathrm{N}$ levels, such as along busy roads with high $\mathrm{N}$ deposition (Ackermann et al. 2012), along natural $\mathrm{N}$ deposition gradients (Rousk et al. 2013; Salemaa et al. 2019) and experimentally fertilized ecosystems (Sorensen et al. 2012). However, $\mathrm{N}_{2}$ fixation in moss-cyanobacteria associations is not inhibited at all $\mathrm{N}$ input rates and the response among moss species differs. For instance, $\mathrm{N}_{2}$ fixation is even promoted in the moss Hylocomium splendens in the laboratory when adding $5 \mathrm{~kg} \mathrm{~N} \mathrm{ha}^{-1} \mathrm{yr}^{-1}$ (Rousk \& Michelsen 2016), unresponsive in Sphagnum magellanicum and S. papillosum after adding 8-32 $\mathrm{kg} \mathrm{N} \mathrm{ha}^{-1} \mathrm{yr}^{-1}$ in peat bogs (van den Elzen et al. 2018), and inhibited in Pleurozium schreberi (Brid.) Mitt. by $3 \mathrm{~kg} \mathrm{~N} \mathrm{ha}^{-1} \mathrm{yr}^{-1} \mathrm{~N}$ deposition in boreal forests of northern Sweden (Gundale et 
al. 2011). These different findings among studies could be the result of different moss species investigated. Diazotrophs associated with e.g. Sphagnum mosses reside inside specialized cells (hyalocytes), while diazotrophs associated with other mosses such as $P$. schreberi, live epiphytically on the moss leaves (Bragina et al. 2012; DeLuca et al. 2002). This leaves Sphagnum-associated diazotrophs more protected against environmental fluctuations, including $\mathrm{N}$ deposition, compared to diazotrophs associated with $P$. schreberi. Thus, although $\mathrm{N}$ input can impede $\mathrm{N}_{2}$ fixation in mosses, the thresholds of $\mathrm{N}$ input above which $\mathrm{N}_{2}$ fixation is inhibited is not well defined and likely differs among species.

Besides the input from $\mathrm{N}_{2}$ fixation, mosses can receive $\mathrm{N}$ via atmospheric deposition (Zechmeister et al. 2007), which contain both inorganic and organic $N$ forms (Cornell et al. 2003; Jia et al. 2016). Organic $N$ deposition can contribute $\sim 20 \%$ to total $\mathrm{N}$ deposition (Cornell 2011; Violaki et al. 2010). Even though mosses prefer chemically simpler inorganic $\mathrm{N}$, i.e. $\mathrm{NH}_{4}{ }^{+}$to organic $\mathrm{N}$ (Forsum et al. 2006; Liu et al. 2013), mosses are able to take up and use organic $\mathrm{N}$ forms such as amino acids and urea (Krab et al. 2008; Nasholm et al. 2009; Persson \& Nasholm 2001; Rousk et al. 2013; Witte 2011). While inorganic $N$ can suppress $\mathrm{N}_{2}$ fixation associated with mosses (see above), how organic $\mathrm{N}$ affects $\mathrm{N}_{2}$ fixation by cyanobacteria on mosses has not been explored to date.

Though $\mathrm{N}_{2}$ fixation can be inhibited by $\mathrm{N}$ inputs, moss-cyanobacteria associations can show resilience towards increased $\mathrm{N}$ deposition. For instance, negative effects of high $\mathrm{N}$ inputs $\left(>12 \mathrm{~kg} \mathrm{~N} \mathrm{ha}^{-1} \mathrm{yr}^{-1}\right)$ on moss-associated $\mathrm{N}_{2}$ fixation disappeared quickly after $\mathrm{N}$ input ceased (within 2 weeks) (Rousk et al. 2014a) and no effects on $\mathrm{N}_{2}$ fixation in mosses by long-term $\mathrm{N}$ additions (0-50 $\mathrm{kg} \mathrm{N} \mathrm{ha}^{-1} \mathrm{yr}^{-1}$ ) were found (Gundale et al. 2013). Recovery of moss-associated $\mathrm{N}_{2}$ fixation has even been found after adding very high $\mathrm{N}$ loads (5-320 kg N ha-1 $\mathrm{yr}^{-1}$ ), providing only 2 weeks of recovery (Rousk \& Michelsen 2016). However, these studies focused on inorganic $\mathrm{N}$, but if $\mathrm{N}_{2}$ fixation can recover from organic $\mathrm{N}$ input is unknown.

Hence, the aim of this study was to investigate how moss-associated $\mathrm{N}_{2}$ fixation responds to and recovers from different forms and rates of $\mathrm{N}$, and how this differs between physiologically contrasting moss species. To do this, we measured $\mathrm{N}_{2}$ fixation rates of two dominant boreal moss species, $P$. schreberi and Sphagnum capillifolium, after the addition of three forms of $\mathrm{N}$, one inorganic (ammonium nitrate, henceforth $\mathrm{NH}_{4} \mathrm{NO}_{3}$ ) and two organic forms (alanine and urea), with low $\mathrm{N}$ additions ("realistic") for several weeks, followed by a period of $\mathrm{N}$ deprivation (recovery period). We then added extreme $\mathrm{N}$ rates and concluded with another period of $\mathrm{N}$ deprivation to assess if different $\mathrm{N}$ rates affect recovery from $\mathrm{N}$ stress. We also assessed moss $\mathrm{pH}, \mathrm{N}$ content as well as cyanobacterial biomass to assess if the $\mathrm{N}$ additions lead to changes in those factors that could affect $\mathrm{N}_{2}$ fixation. We hypothesized that $(\mathrm{H} 1)$ mossassociated $\mathrm{N}_{2}$ fixation rates decrease with increasing $\mathrm{N}$ addition; (H2) thresholds for inhibition depend on the forms of added $\mathrm{N}$, following this sequence from largest inhibition to smallest inhibition of $\mathrm{N}_{2}$ fixation: $\mathrm{NH}_{4} \mathrm{NO}_{3}$ > alanine > urea; $(\mathrm{H} 3) \mathrm{N}_{2}$ fixation rates will be higher during recovery after the realistic $\mathrm{N}$ loads compared to rates after the extreme $\mathrm{N}$ loads; $(\mathrm{H} 4) \mathrm{N}_{2}$ fixation associated with $P$. schreberi is more 
sensitive to $\mathrm{N}$ additions than $\mathrm{S}$. capillifolium due to the different locations of diazotrophs in the two moss hosts.

\section{Material And Methods Sampling}

Moss material was collected in August 2020 from a boreal forest site $\left(65^{\circ} 55^{\prime} 10.62^{\prime \prime} \mathrm{N}, 19^{\circ} 42^{\prime} 22.38^{\prime \prime} \mathrm{E}\right)$ close to Arvidsjaur, Northern Sweden. The mean annual temperature and precipitation are $1{ }^{\circ} \mathrm{C}$ and $570 \mathrm{~mm}$, respectively. The dominant vegetation was composed of Vaccinium vitis-idaea, V. myrtillus, Empetrum hermaphroditum, Hylocomium splendens, Pleurozium schreberi as well as Picea abies, Pinus sylvestris. Individual moss shoots of $P$. schreberi and S. capillifolium were collected from ca. 10 patches within a sampling plot $(n=6)$. Replicate plots were at least $2 \mathrm{~m}$ apart from each other. The moss samples were kept in transparent ziplock bags and transported to Copenhagen. Here, the samples were kept at $4^{\circ} \mathrm{C}$ in the dark until the start of the experiment (ca. 4 months). Mosses can handle this type of storage and still maintain normal function when re-exposed to light (Rousk et al. 2014b)

\section{Experimental setup}

To ensure optimal conditions after storage, moss samples were water saturated by soaking in double distilled water $\left(\mathrm{ddH}_{2} \mathrm{O}\right)$ for ca. ten minutes. Eight shoots of $P$. schreberi and 10 shoots of $S$. capillifolium, representing a ground area of approx. $10 \mathrm{~cm}^{2}$ were weighted and transferred into $20 \mathrm{ml}$ glass tubes. Glass tubes with mosses were kept in a growth chamber at $10^{\circ} \mathrm{C}$ for $18 \mathrm{~h}$ in light and at $6^{\circ} \mathrm{C}$ for $6 \mathrm{~h}$ in darkness for one week before the $\mathrm{N}$ addition and throughout the whole experiment.

Effects of three $\mathrm{N}$ forms $\left(\mathrm{NH}_{4} \mathrm{NO}_{3}\right.$, alanine, urea) on $\mathrm{N}_{2}$ fixation were tested at realistic rates $(0,0.4,2,4 \mathrm{~kg}$ $\left.\mathrm{N} \mathrm{ha}^{-1} \mathrm{yr}^{-1}\right)$ and extreme rates $\left(0,2,10,20 \mathrm{~kg} \mathrm{~N} \mathrm{ha}^{-1} \mathrm{yr}^{-1}\right)$. The realistic $\mathrm{N}$ addition rates were based on background total $\mathrm{N}$ deposition rates of ca. $2 \mathrm{~kg} \mathrm{~N} \mathrm{ha}^{-1} \mathrm{yr}^{-1}$ in these systems (Pihl-Karlsson et al. 2012), and a doubling of that $\left(4 \mathrm{~kg} \mathrm{~N} \mathrm{ha}^{-1} \mathrm{yr}^{-1}\right)$. The $0.4 \mathrm{~kg} \mathrm{~N} \mathrm{ha}^{-1} \mathrm{yr}^{-1}$ corresponds to the proportion of organic $\mathrm{N}$ in total background $\mathrm{N}$ deposition (Cornell 2011; Violaki et al. 2010). For the extreme rates, we added 5 times the "realistic" rates as this would exceed the suggested threshold of $15 \mathrm{~kg} \mathrm{~N} \mathrm{ha}^{-1} \mathrm{yr}^{-1}$ for ecosystem processes (Bobbink et al. 2010) and allow us to explore a wide range of rates.

Treatments with $\mathrm{N}$ began in January 2021. At each $\mathrm{N}$ addition event, $0.5 \mathrm{ml} \mathrm{N}$ solutions or $\mathrm{dd}_{2} \mathrm{O}$ were added to the mosses and the control, respectively, with six replicates for each $\mathrm{N}$ addition, $\mathrm{N}$ form and moss species (totaling to 120 samples). The $\mathrm{N}$ solutions were added weekly over a period of two weeks, i.e., $1 / 2$ rate of the final rate. This was done to not stress moss and associated diazotrophs too much. Hence, the realistic rates were added to the mosses in week 1 and week2, followed by two weeks (week3 and week4) of recovery time with $\mathrm{dd}_{2} \mathrm{O}$ addition only to keep the mosses moist, if necessary. After the first recovery period, the extreme rates were added over the course of two weeks (week5 and week6). The experiment was concluded with another recovery period of 1 week (week7). 


\section{Acetylene reduction assay}

Nitrogen fixation rates were measured using the acetylene reduction assay (ARA) as previously described (Zackrisson et al. 2004). The ARA is based on the preferential reduction of acetylene to ethylene by the nitrogenase enzyme. Hence, it is a direct measure of the nitrogenase enzyme activity, is non-destructive and thus allows measurements over time on the same sample. Acetylene reduction was measured immediately after each $\mathrm{N}$ addition and during the recovery weeks, 7 times in total. For the incubations, each $20 \mathrm{ml}$ tube was sealed and $10 \%$ of the headspace was replaced with acetylene gas. Moss samples were incubated for $24 \mathrm{~h}$ in the growth chamber with the settings described above. Ethylene generated in the headspace was measured by gas chromatography on an Agilent $8890 \mathrm{GC}$ coupled to a headspace sampler and fitted with a FID (Agilent Technologies, Santa Clara, California, USA). For testing the natural production of ethylene by mosses, moss samples without acetylene gas were also incubated under the same conditions as described above. No natural production of ethylene was detected.

\section{$\mathrm{pH}$}

To assess if the added $\mathrm{N}$ solutions lead to changes in moss $\mathrm{pH}$, half of the moss shoots from each sample were moved into $50 \mathrm{ml}$ centrifuge tubes after the final ARA, and $10 \mathrm{ml} \mathrm{ddH_{2 }} \mathrm{O}$ was added. The tubes were shaken for $1 \mathrm{~h}$ and the $\mathrm{pH}$ of the solution was measured using a $\mathrm{pH}$ meter (Sevencompact S220, Mettler Toledo, Shanghai, China). All moss shoots, including those used for $\mathrm{pH}$ measurement were dried at $45^{\circ} \mathrm{C}$ for $>24 \mathrm{~h}$ to measure total dry weight.

\section{Phycocyanin and $\mathrm{N}$ content}

The remainder of the moss shoots not used for $\mathrm{pH}$ measurements were ground and used for phycocyanin and total $\mathrm{N}$ measurements. Phycocyanin pigment extraction and quantification is an easy and efficient way to estimate moss-associated cyanobacterial biomass as phycocyanin is a cyanobacterial specific pigment (Renaudin et al. 2021). Approximately $0.08-0.1 \mathrm{~g}$ of dry moss sample were placed in $50 \mathrm{ml}$ centrifuge tubes with $10 \mathrm{ml}$ of sterilized sodium phosphate buffer $(0.025 \mathrm{M}, \mathrm{pH}=7)$. Then, the moss samples were mixed by vortexing and shaking manually for $10 \mathrm{~s}$. Samples were then subjected to two freeze-thaw cycles ( $2 \mathrm{~h}$ at $-20^{\circ} \mathrm{C}$ followed by $1 \mathrm{~h}$ at room temperature) and mixed by vortexing for $10 \mathrm{~s}$ between cycles to break the cyanobacteria cell membrane. After sonication for $5 \mathrm{~min}$, samples were centrifuged at $4100 \times \mathrm{g}$ at $8^{\circ} \mathrm{C}$ for $15 \mathrm{~min}$. Finally, $5-8 \mathrm{ml}$ supernatants were transferred to $15 \mathrm{ml}$ tubes covered with aluminum foil and stored in dark at $-80^{\circ} \mathrm{C}$ until analysis. Phycocyanin was quantified using a Synergy HT Microplate Reader (BioTek Instruments, Inc, Winooski, VT, USA) with excitation at $590 \mathrm{~nm}$ and emission at $645 \mathrm{~nm}$. For the analysis of total $\mathrm{N}$ of moss tissue, $4-5 \mathrm{mg}$ dry ground samples were weighed into tin capsules and analyzed on an elemental analyzer (Euro EA 3000 Elemental Analyzer, Eurovector SPA., Milano, Italy)

\section{Data Analysis And Statistics}


Differences in moss $\mathrm{N}$ content, cumulative $\mathrm{N}_{2}$ fixation rates, $\mathrm{pH}$ and phycocyanin content between $\mathrm{N}$ addition rates, forms and moss species were tested with three-way ANOVAs followed by Tukey's Post Hoc Test. All data was log transformed to conform with the assumptions of homoscedasticity. The relationships between $\mathrm{N}$ addition rates, moss $\mathrm{N}$ content, $\mathrm{pH}$ and phycocyanin content and cumulative $\mathrm{N}_{2}$ fixation rates were tested with regression analyses. Except for cumulative $\mathrm{N}_{2}$ fixation rates, values for the regression analyses were final values, measured at the end of the experiment, i.e., after the extreme $\mathrm{N}$ addition scenarios. We also determined the $\mathrm{pH}$ optimum for $\mathrm{N}_{2}$ fixation using a nonlinear regression (bellshaped curve), and how the $\mathrm{N}$ additions affect this optimum. Acetylene reduction response ratios were calculated as $\mathrm{N}_{2}$ fixation rates at different rates and forms of $\mathrm{N}$ addition divided by the rates in the control samples (Zheng et al. 2019). Mixed effect models were conducted to test the effects of $\mathrm{N}$ addition rates on acetylene reduction response ratios under each $\mathrm{N}$ form during the realistic or extreme rates scenarios. All analyses were performed in R (R version 3.6.3, R Core Team, 2020, Vienna Austria).

\section{Results}

\section{Moss tissue $\mathbf{N}$ content}

Moss tissue $\mathrm{N}$ content increased with increasing $\mathrm{N}$ additions for both moss species (Table S1; Fig. 1 ). However, this increase was more pronounced for $P$. schreberi below $\mathrm{N}$ additions of $10 \mathrm{~kg} \mathrm{~N} \mathrm{ha}^{-1} \mathrm{yr}^{-1}$, where $P$. schreberi had lower $\mathrm{N}$ content than $S$. capillifolium. But when the $\mathrm{N}$ additions were higher than $10 \mathrm{~kg} \mathrm{~N} \mathrm{ha}^{-1} \mathrm{yr}^{-1}, P$. schreberi showed higher $\mathrm{N}$ content than $S$. capillifolium. The form of $\mathrm{N}$ addition also influenced moss tissue $\mathrm{N}$ content and adding $\mathrm{NH}_{4} \mathrm{NO}_{3}$ lead to lower moss tissue $\mathrm{N}$ content compared to the organic $\mathrm{N}$ forms.

\section{Effects of $\mathrm{N}$ addition rates and forms on nitrogenase activity}

Under the realistic $\mathrm{N}$ addition scenario, nitrogenase response ratios at or above 1 in most treatments, showed that $\mathrm{N}$ addition rates mostly increased or had no effect on nitrogenase activity (acetylene reduction) in both moss species among $\mathrm{N}$ addition forms (Fig. 2). This was except for $P$. schreberi at $4 \mathrm{~kg}$ $\mathrm{N} \mathrm{ha}^{-1} \mathrm{yr}^{-1}$ of $\mathrm{NH}_{4} \mathrm{NO}_{3}$ and for $S$. capillifolium at $0.4 \mathrm{~kg} \mathrm{~N} \mathrm{~h}^{-1} \mathrm{yr}^{-1}$ as urea (Table 1, Fig. 2), where inhibiting effects were found. Positive effects of added $\mathrm{N}$ were mostly found at intermediate and high rates of organic $\mathrm{N}$ but not when inorganic $\mathrm{N}$ was added.

In the extreme scenario, $\mathrm{N}$ addition (after week 4 ) generally decreased nitrogenase activity (Table 1), as seen by the response ratios below 1 in most treatments (Fig. 2). For the $\mathrm{NH}_{4} \mathrm{NO}_{3}$ and urea additions, nitrogenase activity decreased with increasing $\mathrm{N}$ addition rates in both moss species. However, when alanine was added, acetylene reduction response ratios in $P$. schreberi were below 0 only in the two highest $\mathrm{N}$ addition rates (10 and $20 \mathrm{~kg} \mathrm{~N} \mathrm{~h}^{-1} \mathrm{yr}^{-1}$ ), while no inhibition of nitrogenase activity was found when adding alanine to $S$. capillifolium. 
Both moss species recovered to some extent during the $\mathrm{N}$ deprivation phase after the realistic $\mathrm{N}$ addition rates (Figs. 2, S1). As such in $P$. schreberi, acetylene reduction rates almost doubled during the recovery phase in the $\mathrm{NH}_{4} \mathrm{NO}_{3}$ additions ( $1.29 \pm 0.29$ vs. $2.23 \pm 0.31 \mathrm{nmol} \mathrm{g} \mathrm{dw}{ }^{-1} \mathrm{~h}^{-1}$, averages across $\mathrm{N}$ addition rates), and in the urea additions ( $2.63 \pm 0.42$ vs. $\left.4.71 \pm 0.52 \mathrm{nmol} \mathrm{g} \mathrm{dw}^{-1} \mathrm{~h}^{-1}\right)$, while activity remined similar after the alanine treatments $\left(2.07 \pm 0.41\right.$ vs. $\left.2.97 \pm 0.42 \mathrm{nmol} \mathrm{g} \mathrm{dw}^{-1} \mathrm{~h}^{-1}\right)$. For S. capillifolium nitrogenase activity was 2 to 3 times higher after $\mathrm{N}$ addition irrespective of $\mathrm{N}$ form. However, no recovery was found after the extreme $\mathrm{N}$ addition scenario (Fig S1), and acetylene reduction rates were significantly higher $(p<0.001)$ in both moss species in the recovery period after the realistic additions compared to the extreme additions, irrespective of $\mathrm{N}$ form $\left(2.82 \pm 0.31\right.$ vs. $1.54 \pm 0.24 \mathrm{nmol} \mathrm{g} \mathrm{dw}^{-1} \mathrm{~h}^{-1}$, for $P$. schreberi and S. capillifolium, respectively).

\section{Cumulative nitrogenase activity - response pattern over 7 weeks}

The cumulative acetylene reduction ( $\mathrm{N}_{2}$ fixation rates from the $\mathrm{N}$ addition and $\mathrm{N}$ deprivation periods) after 7 weeks differed between the two moss species (Table S1) and was higher in S. capillifollium than in $P$. schreberi in the $\mathrm{NH}_{4} \mathrm{NO}_{3}(p<0.05)$ and alanine additions $(p<0.1)$, but not in the urea additions (Fig. 3 ). Also, the effects of addition rate depended on the $\mathrm{N}$ form (Table S1). As such, $\mathrm{NH}_{4} \mathrm{NO}_{3}$ decreased acetylene reduction, while alanine increased cumulative acetylene reduction $\left(R^{2}=0.87, p=0.06 ; R^{2}=0.99\right.$, $p=0.07$; for $P$. schreberi and S. capillifolium, respectively, Fig. 3).

\section{Moss pH}

Moss $\mathrm{pH}$ changed with $\mathrm{N}$ addition rate but the specific effect depended on species and $\mathrm{N}$ form (Table S1, Fig. 4). Moss $\mathrm{pH}$ increased with increasing alanine and urea additions in both moss species, and here $P$. schreberi had higher $\mathrm{pH}$ than S. capillifolium (Fig. 4). However, when $\mathrm{NH}_{4} \mathrm{NO}_{3}$ was added, moss $\mathrm{pH}$ decreased and this was more pronounced in P. schreberi than in $S$. capillifolium. The optimum $\mathrm{pH}$ for $\mathrm{N}_{2}$ fixation decreased with $\mathrm{N}$ additions in $P$. schreberi from 5.33 (control samples) to 5.03 ( $\mathrm{N}$ addition samples) but increased from 4.83 to 5.18 in $S$. capillifolium. But overall, $\mathrm{N}_{2}$ fixation in P. schreberi (5.06) had a higher optimum pH than S. capillifolium (4.91, Fig S2).

\section{Phycocyanin}

Phycocyanin concentration, which is a measure of cyanobacterial biomass, was significantly affected by $\mathrm{N}$ addition rates, forms and moss species (Table S1). Phycocyanin concentrations increased with increasing alanine and urea additions in S. capillifolium $\left(\mathrm{R}^{2}=0.73, p=0.094 ; \mathrm{R}^{2}=0.89, p=0.037 ;\right.$ Fig. 5), which were significantly higher than in $P$. schreberi $(p<0.05)$. The $\mathrm{NH}_{4} \mathrm{NO}_{3}$ addition did not lead to any changes in phycocyanin concentrations.

\section{Discussion}


Nitrogen fixation in mosses is the primary input of $\mathrm{N}$ in pristine ecosystems. Nitrogen deposition is expected to increase due to increased human influence with the presumed outcome that $\mathrm{N}_{2}$ fixation will decrease. However, $\mathrm{N}$ deposition consists of $\sim 20 \%$ organic $\mathrm{N}$, and we have very limited knowledge about how this influences $\mathrm{N}_{2}$ fixation in mosses. This study suggests that organic $\mathrm{N}$ has very different and often positive effects on $\mathrm{N}_{2}$ fixation. Below we discuss the details and consequences of these findings.

\section{Effects of $\mathrm{N}$ additions on moss-associated $\mathrm{N}_{2}$ fixation}

Nitrogen additions increased $\mathrm{N}$ content in the mosses, which indicated that the mosses absorbed the exogenous $N$. Hence, we can address our hypotheses. We hypothesized $(\mathrm{H} 1)$ that $\mathrm{N}_{2}$ fixation in two common moss species would decrease with increasing $\mathrm{N}$ additions. However, this was only partly confirmed, as $\mathrm{N}_{2}$ fixation response to $\mathrm{N}$ additions was highly dependent on $\mathrm{N}$ form and moss species. The realistic $\mathrm{NH}_{4} \mathrm{NO}_{3}$ addition (0.4-4 $\mathrm{kg} \mathrm{N} \mathrm{ha}^{-1} \mathrm{yr}^{-1}$ ) followed the expected pattern with lower $\mathrm{N}_{2}$ fixation rates with increasing rates as also seen in boreal forest (Gundale et al. 2011; Rousk \& Michelsen 2016). Interestingly, addition of alanine and urea had positive or no effects on $\mathrm{N}_{2}$ fixation in this experiment (see below). Usually, the nitrogenase enzyme is depressed by its end product, i.e., ammonia. Besides, $\mathrm{NH}_{4} \mathrm{NO}_{3}$ causes acidification (Tian \& Niu 2015), and low pH can inhibit $\mathrm{N}_{2}$ fixation in mosses (Alvarenga \& Rousk 2021), as a result of suppressed nitrogenase enzyme activity (see below).

According to our second hypothesis ( $\mathrm{H} 2)$, more complex $\mathrm{N}$ forms, alanine and urea, showed a higher threshold for inhibiting $\mathrm{N}_{2}$ fixation and often benefitted $\mathrm{N}_{2}$ fixation at low rates compared to $\mathrm{NH}_{4} \mathrm{NO}_{3}$, as $\mathrm{NH}_{4} \mathrm{NO}_{3}$ inhibited activity already at 2-4 $\mathrm{kg} \mathrm{N} \mathrm{ha}^{-1} \mathrm{yr}^{-1}$ for $P$. schreberi and around $10 \mathrm{~kg} \mathrm{~N} \mathrm{ha}^{-1} \mathrm{yr}^{-1}$ for $S$. capillifolium, while 10 and $20 \mathrm{~kg} \mathrm{~N} \mathrm{ha}^{-1} \mathrm{yr}^{-1}$ with alanine addition for $P$. schreberi and $S$. capillifolium, respectively, and urea inhibited $\mathrm{N}_{2}$ fixation only at the highest rate $\left(20 \mathrm{~kg} \mathrm{~N} \mathrm{ha}^{-1} \mathrm{yr}^{-1}\right)$ for both species (Figs. 2, S1). Surprisingly, realistic additions of alanine and urea did not inhibit $\mathrm{N}_{2}$ fixation in either species, but rather, promoted $\mathrm{N}_{2}$ fixation. A possible explanation is that the organic $\mathrm{N}$ forms were allocated towards growth by both cyanobacteria and moss and therefore, did not inhibit $\mathrm{N}_{2}$ fixation (Krausfeldt et al. 2019; Liu et al. 2013; Rawson 1985). Indeed, phycocyanin concentration, as a measure of cyanobacterial abundance, did increase in both species after adding organic $\mathrm{N}$ (only a trend in $P$. schreberi) but not after adding inorganic N. Moreover, organic nitrogen could also act as a carbon source for cyanobacteria (Krausfeldt et al. 2019), which could save the cost for photosynthesis and allow more energy to be invested to fix $\mathrm{N}_{2}$. Another positive, but indirect effect of organic $\mathrm{N}$, is the increase in moss $\mathrm{pH}$ that can promote $\mathrm{N}_{2}$ fixation activity (e.g. (Alvarenga \& Rousk)). Further, amino acids can be absorbed and utilized directly by moss and cyanobacteria, and the assimilation cost of amino acids is considered to be lower than that of $\mathrm{NH}_{4}{ }^{+}$and much lower than that of $\mathrm{NO}_{3}{ }^{-}$(Liu et al. 2013; Song et al. 2016). Urea likely offers the greatest energetic advantage because urea hydrolysis by urease results in the production of two $\mathrm{N}$ containing molecules (Herrero et al. 2001). Moreover, the breakdown of urea results in the release of $\mathrm{CO}_{2}$ as a by-product, which can be incorporated into photosynthesis, reducing the reliance on 
active uptake (Glibert et al. 2014). Hence, different uptake - and metabolism mechanisms lead to the diverse response patterns of $\mathrm{N}_{2}$ fixation towards different types of $\mathrm{N}$. This is also reflected in the higher moss tissue $\mathrm{N}$ content in both investigated moss species after organic than inorganic $\mathrm{N}$ additions, suggesting different uptake strategies or requirements for inorganic vs. organic $\mathrm{N}$ (Krab et al. 2008; Liu et al. 2013).

Under the extreme $\mathrm{N}$ addition scenario, all three $\mathrm{N}$ forms inhibited $\mathrm{N}_{2}$ fixation, although inorganic $\mathrm{N}$ had the strongest effect. The inhibition could be explained by $\mathrm{pH}$ stress and toxicity caused by high $\mathrm{N}$ concentrations. In this study, high rates of $\mathrm{N}$ additions changed the $\mathrm{pH}$ optimum for $\mathrm{N}_{2}$ fixation - above or below the $\mathrm{pH}$ optimum in the control samples, depending on moss species. The $\mathrm{pH}$ optimum for $\mathrm{N}_{2}$ fixation in both species was lower than the $\mathrm{pH}$ of $5.9 \sim 6.2$ found by Smith (1984) and may be due to different moss species investigated. High rates of added $\mathrm{NH}_{4} \mathrm{NO}_{3}$ decreased $\mathrm{pH}$ while alanine and urea increased moss pH. Rawson (1985) found that several amino acids affected nitrogenase and appeared to be toxic at high concentrations in culture $(10 \mathrm{mM})$. The hydrolysis of urea produces two ammonia molecules, which can be protonated to form two $\mathrm{NH}_{4}{ }^{+}$molecules and cause an increase in pH (Carlini \& Ligabue-Braun 2016; Herrero et al. 2001; Veaudor et al. 2019), thus under the extreme urea addition, high $\mathrm{NH}_{4}{ }^{+}$accumulation and high $\mathrm{pH}$ (average $\mathrm{pH}$ in both species was 5.67 after urea addition) may account for inhibition of $\mathrm{N}_{2}$ fixation. Even though we found inhibition of $\mathrm{N}_{2}$ fixation by alanine and urea at high rates, in natural ecosystems, organic $\mathrm{N}$ contributes $20-30 \%$ to total $\mathrm{N}$ deposition (Cornell 2011; Violaki et al. 2010), which means in natural ecosystems organic $N$ inputs are much lower than our extreme addition rates and could promote $\mathrm{N}_{2}$ fixation. Besides, in natural environments available $\mathrm{N}$ is always complex and mixed. A preference to take up different $\mathrm{N}$ forms such as ammonium, nitrate, amino acids, urea should therefore be taken into account when considering the $\mathrm{N}$ addition effects on $\mathrm{N}_{2}$ fixation (Andersen et al. 2020; Liu et al. 2013).

\section{Recovery of $\mathrm{N}_{2}$ fixation after $\mathrm{N}$ additions}

Since organic $\mathrm{N}$ did not inhibit $\mathrm{N}_{2}$ fixation in the realistic $\mathrm{N}$ addition scenario, recovery from the $\mathrm{N}$ stress can strictly speaking not occur. Nonetheless, given that we expected an inhibition of $\mathrm{N}_{2}$ fixation by all $\mathrm{N}$ forms, we deprived the mosses of $\mathrm{N}$ for 2 weeks, and we found inhibition after the extreme $\mathrm{N}$ addition scenario, we still define the $\mathrm{N}_{2}$ fixation rates during the $\mathrm{N}$ deprivation period as recovery rates. In line with our third hypothesis ( $\mathrm{H} 3$ ), we found evidence for higher recovery of $\mathrm{N}_{2}$ fixation after lower $\mathrm{N}$ additions than in the extreme $\mathrm{N}$ addition scenario. Also, a higher recovery rate was found with urea addition than with $\mathrm{NH}_{4} \mathrm{NO}_{3}$ or alanine addition in both moss species during the $\mathrm{N}$ deprivation after the realistic scenario but not after the extreme scenario, which may be because low rates of urea additions increased moss $\mathrm{pH}$ (5.22 5.52 for $P$. schreberi and 4.68 4.92 for $S$. capillifolium) more than $\mathrm{NH}_{4} \mathrm{NO}_{3}$ and alanine addition, creating an environment conducive to $\mathrm{N}_{2}$ fixation. Urea also provides both $\mathrm{C}$ and $\mathrm{N}$ to cyanobacteria (Krausfeldt et al. 2019). Recovery after $\mathrm{N}$ additions under the realistic scenario suggests that the cyanobacteria may have down-regulated $\mathrm{N}_{2}$ fixation during the $\mathrm{N}$ additions, since $\mathrm{N}_{2}$ fixation is an energy 
consuming process (Sohm et al. 2011; Turetsky 2003). As soon as $\mathrm{N}$ availability is decreasing ( $\mathrm{N}$ deprivation phases), cyanobacteria start fixing $\mathrm{N}_{2}$ again. After extreme $\mathrm{N}$ additions, however, $\mathrm{N}_{2}$ fixation did not recover. Previous studies showed that recovery from high $\mathrm{N}$ loads needs a longer time or $\mathrm{N}$ needs to be actively removed via e.g. rinsing (Rousk et al. 2014a; Rousk \& Michelsen 2016). Therefore, recovery from $\mathrm{N}$ loads is possible, if $\mathrm{N}$ input remains below a certain threshold.

\section{Moss species-specific responses to $\mathbf{N}$ addition}

Although acetylene reduction rates were higher in S. capillifolium than in P. schreberi in this study, the rates still likely underestimate the actual $\mathrm{N}_{2}$ fixation as in Sphagnum, the most dominant diazotrophs are methanotrophs (Bragina et al. 2013; Leppänen et al. 2015), whose activity is suggested to be inhibited by acetylene. Yet, the high acetylene reduction rates in Sphagnum in our study indicate either a high abundance of cyanobacteria present, which are not inhibited by acetylene, or not all methanotrophs are inhibited by acetylene during the incubation period (Rousk et al. 2018).

Throughout the experiment, $P$. schreberi and $S$. capillifolium had comparable average nitrogenase activity in the control and urea treatments. However, nitrogenase activity in $P$. schreberi dropped 3 times after $\mathrm{NH}_{4} \mathrm{NO}_{3}$ addition and halved after alanine additions compared to $S$. capillifolium. The cumulative $\mathrm{N}_{2}$ fixation rates in $P$. schreberi with $\mathrm{NH}_{4} \mathrm{NO}_{3}$ addition was suppressed but not in $S$. capillifolium, and we only found a positive relationship between phycocyanin and $\mathrm{N}$ addition rates in $S$. capillifolium in the alanine and urea treatment. All these results only partly supported $\mathrm{H} 4$, stating that $P$. schreberi would be more sensitive to $\mathrm{N}$ additions than $\mathrm{S}$. capillifolium. Nevertheless, response differences between the moss species could be identified. The higher sensitivity of $\mathrm{N}_{2}$ fixation in $P$. schreberi towards increased inorganic $\mathrm{N}$ may be due to the different colonization locations of cyanobacteria in the two moss hosts. Cyanobacteria colonize the leave surface of $P$. schreberi (DeLuca et al. 2002), causing them to be exposed to the environment directly. Sphagnum mosses harbor microorganisms both on the surface and inside their hyaline cells. Hyaline cells provide a relative stable living space where diazotrophs are protected from N stress (Bragina et al. 2012). Also, S. capillifolium, and Sphagnum species in general, are common in boreal peatlands with usually low pH (Kostka et al. 2016; Turetsky et al. 2012), which could explain why $\mathrm{N}_{2}$ fixation in this species was less responsive to extreme $\mathrm{NH}_{4} \mathrm{NO}_{3}$ additions leading lower $\mathrm{pH}$ (Fig. S2) compared to $P$. schreberi. Higher regression slopes between $\mathrm{N}$ content and $\mathrm{N}$ addition rates found in $P$. schreberi also suggests that $P$. schreberi took up more of the added $\mathrm{N}$ and could be therefore more sensitive to $\mathrm{N}$ inputs than $\mathrm{S}$. capillifolium, leading to $P$. schreberi had lower threshold toward $\mathrm{N}$ inputs (Fig. 1).

\section{Conclusions}

This study illustrates that different $\mathrm{N}$ forms have different impacts on moss- associated $\mathrm{N}_{2}$ fixation with high sensitivity of $\mathrm{N}_{2}$ fixation in $P$. scherberi towards low loads of inorganic $\mathrm{N}$ while organic $\mathrm{N}$ forms can promote $\mathrm{N}_{2}$ fixation in both species. However, importantly we found that high $\mathrm{N}$ inputs -no matter in which form - inhibit $\mathrm{N}_{2}$ fixation. Moss-associated $\mathrm{N}_{2}$ fixation can recover from $\mathrm{N}$ stress, if $\mathrm{N}$ loads do not 
exceed a certain threshold above which $\mathrm{N}_{2}$ fixation is inhibited. Variation in $\mathrm{N}_{2}$ fixation response patterns between the moss species, with inhibition of $\mathrm{N}_{2}$ fixation in $P$. schreberi at 2-4, 10, $20 \mathrm{~kg} \mathrm{~N} \mathrm{ha}^{-1} \mathrm{yr}^{-1}$ by $\mathrm{NH}_{4} \mathrm{NO}_{3}$, alanine and urea addition, respectively, while $S$. capillifolium had higher thresholds for inhibition, at $10,20,20 \mathrm{~kg} \mathrm{~N} \mathrm{ha}^{-1} \mathrm{yr}^{-1}$, is likely the result of differences in the location of the diazotrophs between the moss species (epiphytic vs. endophytic for P. schreberi, S. capillifolium, respectively).

This is the first study to assess the effects of organic $\mathrm{N}$ on moss-associated $\mathrm{N}_{2}$ fixation. The results show that organic $\mathrm{N}$ can promote $\mathrm{N}_{2}$ fixation at low rates and that the threshold for inhibiting $\mathrm{N}_{2}$ fixation is higher than that for inorganic $\mathrm{N}$. Hence, diverse $\mathrm{N}$ sources and species differences should be taken into account when estimating impacts of $\mathrm{N}$ inputs on moss-associated $\mathrm{N}_{2}$ fixation in natural ecosystems.

\section{Declarations}

\section{Acknowledgements}

We thank Danillo O. Alvarenga for collecting and providing the moss samples used in this work. We are grateful to Gosha Sylvester and Esben Nielsen for assistance with laboratory work.

\section{Funding}

This project has received funding from the European Research Council (ERC) under the European Union's Horizon 2020 research and innovation programme (grant agreement No 947719 to KR). Funding was also provided by the Independent Research Fund Denmark (IRFD), Sapere Aude Grant (id: 7027-00011B) to $\mathrm{KR}$.

\section{Ethics declarations}

The authors declare that they have no conflict of interest.

\section{References}

1. Ackermann $\mathrm{K}$, Zackrisson O, Rousk J, Jones DL, DeLuca TH (2012) $\mathrm{N}_{2}$ fixation in feather mosses is a sensitive indicator of $\mathrm{N}$ deposition in boreal forests. Ecosystems 15(6): 986-998

2. Alvarenga DO, Rousk K (2021) Indirect effects of climate change inhibit $\mathrm{N}_{2}$ fixation associated with the feathermoss Hylocomium splendens in subarctic tundra. Sci. Total Environ. 795: 148676

3. Andersen IM, Williamson TJ, González MJ, Vanni MJ (2020) Nitrate, ammonium, and phosphorus drive seasonal nutrient limitation of chlorophytes, cyanobacteria, and diatoms in a hyper-eutrophic reservoir. Limnol. Oceanogr. 65(5): 962-978

4. Bobbink R, Hicks K, Galloway J, Spranger T, Alkemade R, Ashmore M, Bustamante M, Cinderby S, Davidson E, Dentener F, Emmett B, Erisman JW, Fenn M, Gilliam F, Nordin A, Pardo L, De Vries W 
(2010) Global assessment of nitrogen deposition effects on terrestrial plant diversity: a synthesis. Ecol. Appl. 20(1): 30-59

5. Bragina A, Berg C, Cardinale M, Shcherbakov A, Chebotar V, Berg G (2012) Sphagnum mosses harbour highly specific bacterial diversity during their whole lifecycle. Isme Journal 6(4): 802-813

6. Bragina A, Berg C, Mueller H, Moser D, Berg G (2013) Insights into functional bacterial diversity and its effects on Alpine bog ecosystem functioning. Scientific Reports 3(1): 1-8

7. Carlini CR, Ligabue-Braun R (2016) Ureases as multifunctional toxic proteins: A review. Toxicon 110: 90-109

8. Cornell SE (2011) Atmospheric nitrogen deposition: Revisiting the question of the importance of the organic component. Environ. Pollut. 159(10): 2214-2222

9. Cornell SE, Jickells TD, Cape JN, Rowland AP, Duce RA (2003) Organic nitrogen deposition on land and coastal environments: a review of methods and data. Atmos. Environ. 37(16): 2173-2191

10. DeLuca TH, Zackrisson O, Nilsson MC, Sellstedt A (2002) Quantifying nitrogen-fixation in feather moss carpets of boreal forests. Nature 419(6910): 917-920

11. Forsum A, Dahlman L, Nasholm T, Nordin A (2006) Nitrogen utilization by Hylocomium splendens in a boreal forest fertilization experiment. Funct. Ecol. 20(3): 421-426

12. Glibert PM, Maranger R, Sobota DJ, Bouwman L (2014) The Haber Bosch-harmful algal bloom (HBHAB) link. Environmental Research Letters 9(10): 105001

13. Gundale MJ, Bach LH, Nordin A (2013) The impact of simulated chronic nitrogen deposition on the biomass and $\mathrm{N}_{2}$-fixation activity of two boreal feather moss-cyanobacteria associations. Biology Letters 9(6):

14. Gundale MJ, Deluca TH, Nordin A (2011) Bryophytes attenuate anthropogenic nitrogen inputs in boreal forests. Global Change Biol. 17(8): 2743-2753

15. Herrero A, Muro-Pastor AM, Flores E (2001) Nitrogen control in cyanobacteria. J. Bacteriol. 183(2): 411-425

16. Jia YL, Yu GR, Gao YN, He NP, Wang QF, Jiao CC, Zuo Y (2016) Global inorganic nitrogen dry deposition inferred from ground- and space-based measurements. Scientific Reports 6: 1-11

17. Kostka JE, Weston DJ, Glass JB, Lilleskov EA, Shaw AJ, Turetsky MR (2016) The Sphagnum microbiome: new insights from an ancient plant lineage. New Phytol. 211(1): 57-64

18. Krab EJ, Cornelissen JHC, Lang SI, van Logtestijn RSP (2008) Amino acid uptake among wideranging moss species may contribute to their strong position in higher-latitude ecosystems. Plant Soil 304(1-2): 199-208

19. Krausfeldt LE, Farmer AT, Castro Gonzalez HF, Zepernick BN, Campagna SR, Wilhelm SW (2019) Urea is both a carbon and nitrogen source for microcystis aeruginosa: Tracking ${ }^{13} \mathrm{C}$ incorporation at bloom pH conditions. Frontiers in Microbiology 10(1064): 1064

20. Leppänen SM, Rissanen AJ, Tiirola M (2015) Nitrogen fixation in Sphagnum mosses is affected by moss species and water table level. Plant Soil 389(1): 185-196 
21. Liu XY, Koba K, Makabe A, Li XD, Yoh M, Liu CQ (2013) Ammonium first: natural mosses prefer atmospheric ammonium but vary utilization of dissolved organic nitrogen depending on habitat and nitrogen deposition. New Phytol. 199(2): 407-419

22. Nasholm T, Kielland K, Ganeteg U (2009) Uptake of organic nitrogen by plants. New Phytol. 182(1): $31-48$

23. Persson J, Nasholm T (2001) Amino acid uptake: a widespread ability among boreal forest plants. Ecol. Lett. 4(5): 434-438

24. Pihl-Karlsson G, Hellsten S, Karlsson PE, Akselsson C, Ferm M (2012) Kvävedepositionen till Sverige. Jämförelse av depositionsdata från Krondroppsnätet, Luft- och nederbördskemiska nätet samt EMEP. In: B-rapport. vol B2030. IVL Svenska Miljöinstitutet.

25. Rawson DM (1985) The effects of exogenous amino acids on growth and nitrogenase activity in the cyanobacterium Anabaena cylindrica PCC 7122. 131(10): 2549-2554

26. Renaudin M, Darnajoux R, Bellenger JP (2021) Quantification of moss-associated cyanobacteria using phycocyanin pigment extraction. Frontiers in Microbiology 11: 3294

27. Rousk K, Jones DL, DeLuca TH (2014a) Exposure to nitrogen does not eliminate $\mathrm{N}_{2}$ fixation in the feather moss Pleurozium schreberi (Brid.) Mitt. Plant Soil 374(1-2): 513-521

28. Rousk K, Jones DL, DeLuca TH (2014b) The resilience of nitrogen fixation in feather moss (Pleurozium schreberi)-cyanobacteria associations after a drying and rewetting cycle. Plant Soil 377(1): 159-167

29. Rousk K, Michelsen A (2016) The sensitivity of moss-associated nitrogen fixation towards repeated nitrogen input. Plos One 11(1): e0146655

30. Rousk K, Rousk J, Jones DL, Zackrisson O, DeLuca TH (2013) Feather moss nitrogen acquisition across natural fertility gradients in boreal forests. Soil Biology \& Biochemistry 61: 86-95

31. Rousk K, Sorensen PL, Michelsen A (2017) Nitrogen fixation in the high Arctic: a source of 'new' nitrogen? Biogeochemistry 136(2): 213-222

32. Rousk K, Vestergard M, Christensen S (2018) Are nitrous oxide emissions and nitrogen fixation linked in temperate bogs? Soil Biology \& Biochemistry 123: 74-79

33. Salemaa M, Lindroos A-J, Merila P, Makipaa R, Smolander A (2019) $\mathrm{N}_{2}$ fixation associated with the bryophyte layer is suppressed by low levels of nitrogen deposition in boreal forests. Sci. Total Environ. 653: 995-1004

34. Smith VR (1984) Effects of abiotic factors on acetylene reduction by cyanobacteria epiphytic on moss at a subantarctic island. Appl. Environ. Microbiol. 48(3): 594-600

35. Sohm JA, Webb EA, Capone DG (2011) Emerging patterns of marine nitrogen fixation. Nature Reviews Microbiology 9(7): 499-508

36. Song L, Lu HZ, Xu XL, Li S, Shi XM, Chen X, Wu Y, Huang JB, Chen Q, Liu S, Wu CS, Liu WY (2016) Organic nitrogen uptake is a significant contributor to nitrogen economy of subtropical epiphytic bryophytes. Scientific Reports 6: 1-9 
37. Sorensen PL, Lett S, Michelsen A (2012) Moss-specific changes in nitrogen fixation following two decades of warming, shading, and fertilizer addition. Plant Ecol. 213(4): 695-706

38. Tian DS, Niu SL (2015) A global analysis of soil acidification caused by nitrogen addition. Environmental Research Letters 10(2):

39. Turetsky MR (2003) The role of bryophytes in carbon and nitrogen cycling. Bryologist 106(3): 395409

40. Turetsky MR, Bond-Lamberty B, Euskirchen E, Talbot J, Frolking S, McGuire AD, Tuittila ES (2012) The resilience and functional role of moss in boreal and arctic ecosystems. New Phytol. 196(1): 49-67

41. van den Elzen E, van den Berg LJL, van der Weijden B, Fritz C, Sheppard LJ, Lamers LPM (2018) Effects of airborne ammonium and nitrate pollution strongly differ in peat bogs, but symbiotic nitrogen fixation remains unaffected. Sci. Total Environ. 610: 732-740

42. Veaudor T, Cassier-Chauvat C, Chauvat F (2019) Genomics of urea transport and catabolism in cyanobacteria: biotechnological implications. Frontiers in Microbiology 10(2052): 2052

43. Violaki K, Zarbas P, Mihalopoulos N (2010) Long-term measurements of dissolved organic nitrogen (DON) in atmospheric deposition in the Eastern Mediterranean: Fluxes, origin and biogeochemical implications. Mar. Chem. 120(1-4): 179-186

44. Witte C-P (2011) Urea metabolism in plants. Plant Sci. 180(3): 431-438

45. Zackrisson O, DeLuca TH, Nilsson MC, Sellstedt A, Berglund LM (2004) Nitrogen fixation increases with successional age in boreal forests. Ecology 85(12): 3327-3334

46. Zechmeister HG, Dirnbock T, Hulber K, Mirtl M (2007) Assessing airborne pollution effects on bryophytes - lessons learned through long-term integrated monitoring in Austria. Environ. Pollut. 147(3): 696-705

47. Zheng MH, Zhou ZH, Luo YQ, Zhao P, Mo JM (2019) Global pattern and controls of biological nitrogen fixation under nutrient enrichment: A meta-analysis. Global Change Biol. 25(9): 3018-3030

\section{Tables}

Due to technical limitations, table 1 is only available as a download in the Supplemental Files section.

\section{Figures}


Fig. 1
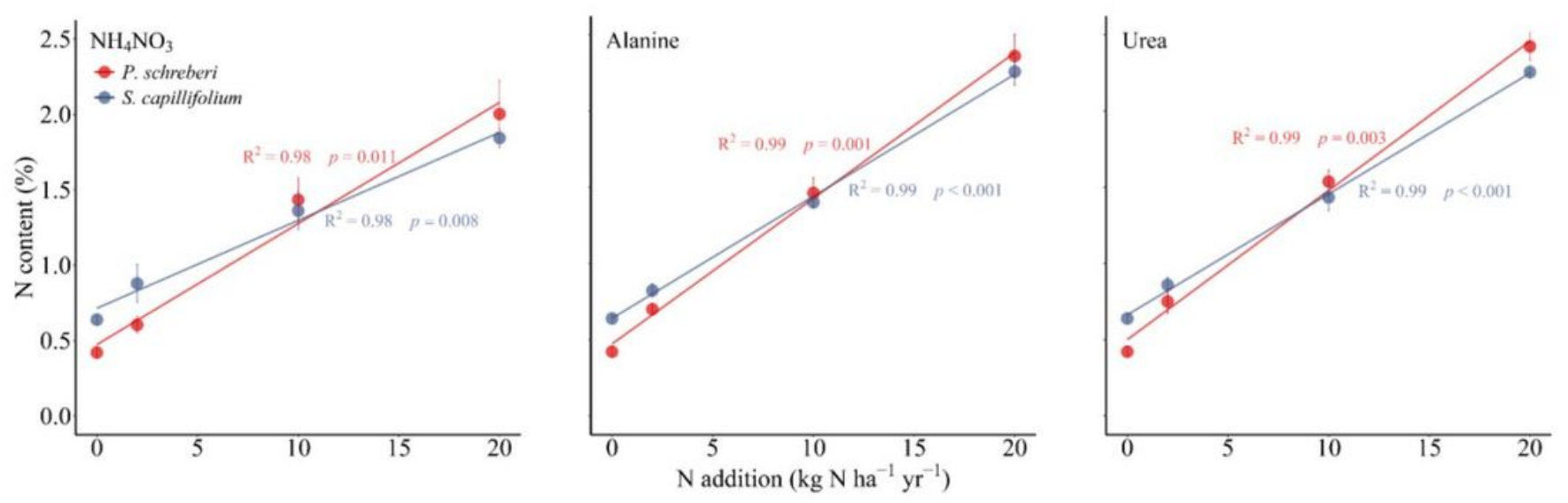

\section{Figure 1}

Moss tissue $\mathrm{N}$ content (\%) in two moss species Pleurozium schreberi (red) and Sphagnum capilifollium (blue) at the end of the experiment after different $\mathrm{N}$ addition rates (extreme $\mathrm{N}$ addition rates: 0, 0.4, 2 and $4 \mathrm{~kg} \mathrm{~N}$ ha-1 yr-1) and N forms (NH4NO3, urea and alanine). Given are mean values $\pm S E(n=6)$. 
Fig. 2
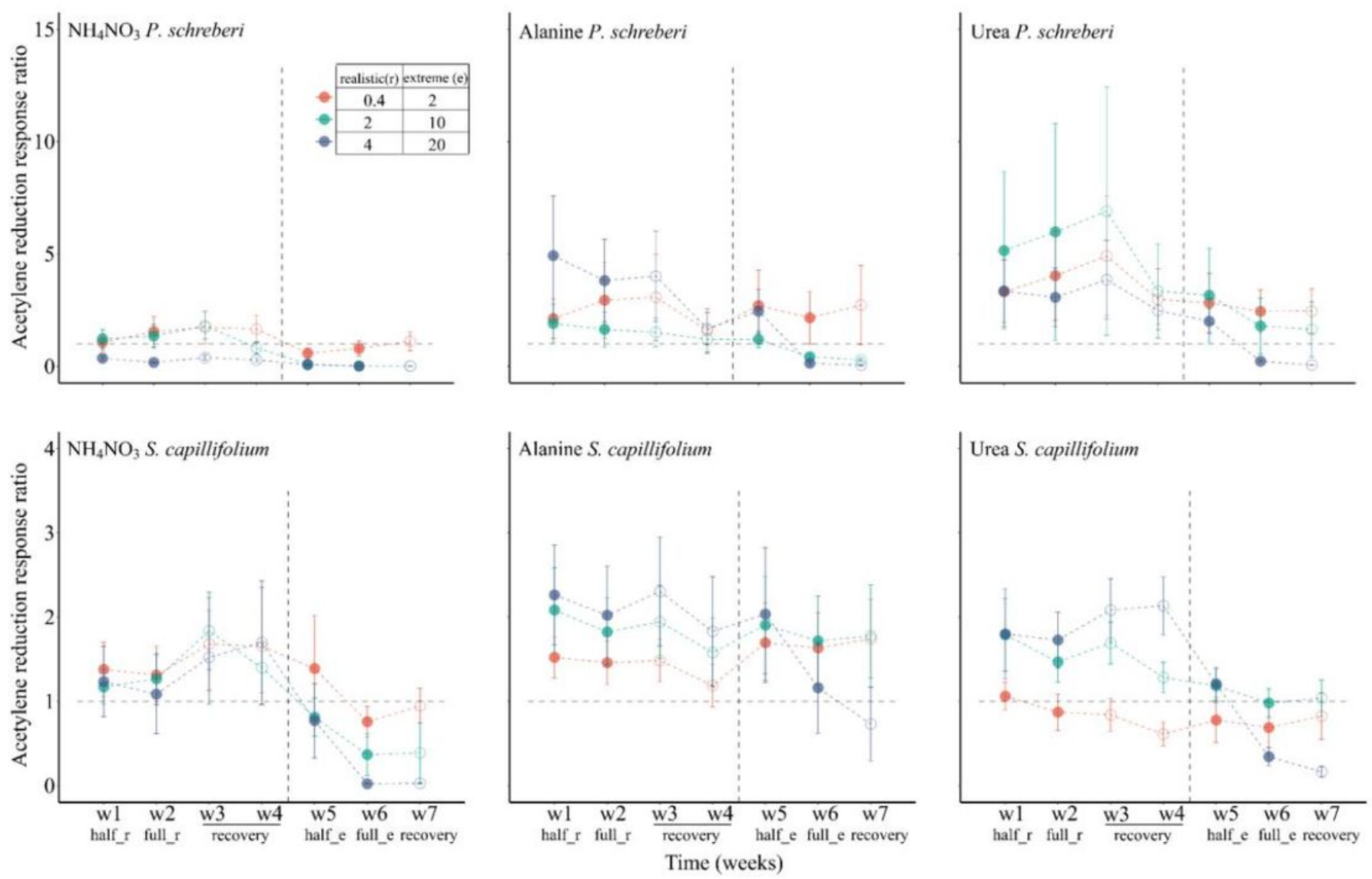

Figure 2

Acetylene reduction response ratio at different $\mathrm{N}$ addition rates and forms in two moss species (P. schreberi in red, S. capillifolium in blue) measured each week during the experiment relative to controls. Given are means \pm SE $(n=6)$. On the $x$ axes, half_r and full_r correspond to samples that received half or the full amount of the realistic $\mathrm{N}$ addition, and half_e and full_e represent samples that received half or the full amount of the extreme $\mathrm{N}$ addition. During recovery weeks, samples received only ddH2O. On the left side of the vertical dotted lines are the realistic $\mathrm{N}$ additions $(0,0.4,2$ and $4 \mathrm{~kg} \mathrm{~N}$ ha- $1 \mathrm{yr}-1)$ and on the right side are the extreme $\mathrm{N}$ additions $(0,2,10,20 \mathrm{~kg} \mathrm{~N}$ ha-1 $\mathrm{yr}-1)$. Full symbols indicate weeks where $\mathrm{N}$ was added, while open symbols indicate recovery weeks. Response ratios with error bars not overlapping $\mathrm{RR}=1$ (horizontal dotted line), indicate that the treatment significantly increased (above the line) or decreased (below the line) ethylene production relative to the control treatment. 
Fig. 3
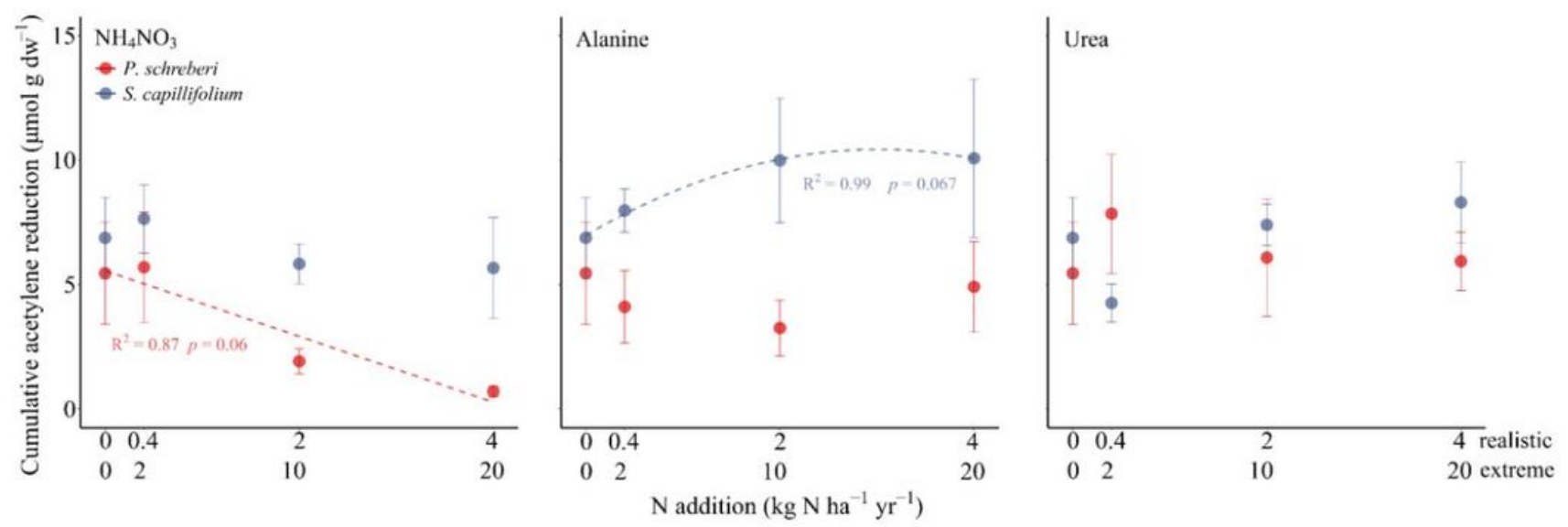

\section{Figure 3}

Cumulative acetylene reduction ( $\mu \mathrm{mol} \mathrm{g} \mathrm{dw}-1)$ in moss samples in response to different $\mathrm{N}$ addition rates and forms in two moss species (P. schreberi, S. capillifolium) over a 7-week period. On the $x$ axes, the first row of number represents the realistic $\mathrm{N}$ additions $(0,0.4,2$ and $4 \mathrm{~kg} \mathrm{~N}$ ha1 $\mathrm{yr}-1)$ and the second row are the extreme $N$ additions $(0,2,10,20 \mathrm{~kg} \mathrm{~N}$ ha- $1 \mathrm{yr}-1)$. Given are means $\pm S E(n=6)$. Solid lines indicate significant relationships at $p<0.05$, while dotted lines indicated relationships at $p<0.1$.

Fig. 4
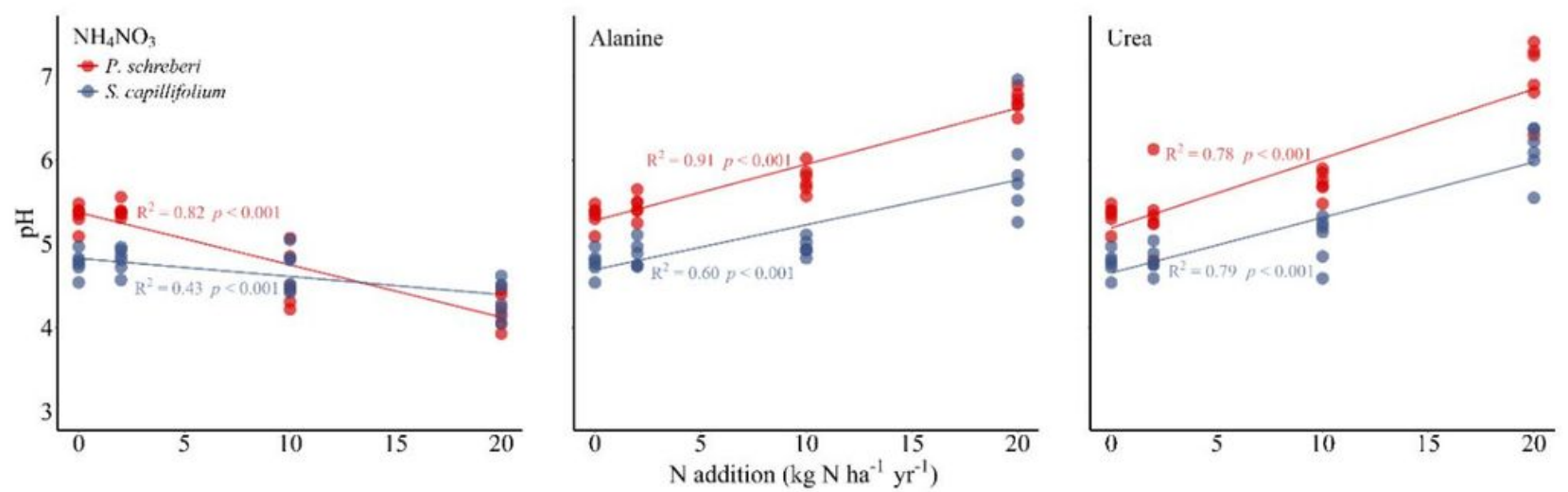

\section{Figure 4}

Moss (P. schreberi, S. capillifolium) $\mathrm{pH}$ (mean $\pm S E, n=6$ ) exposed to different $\mathrm{N}$ rates and forms at the end of the experiment. 
Fig. 5
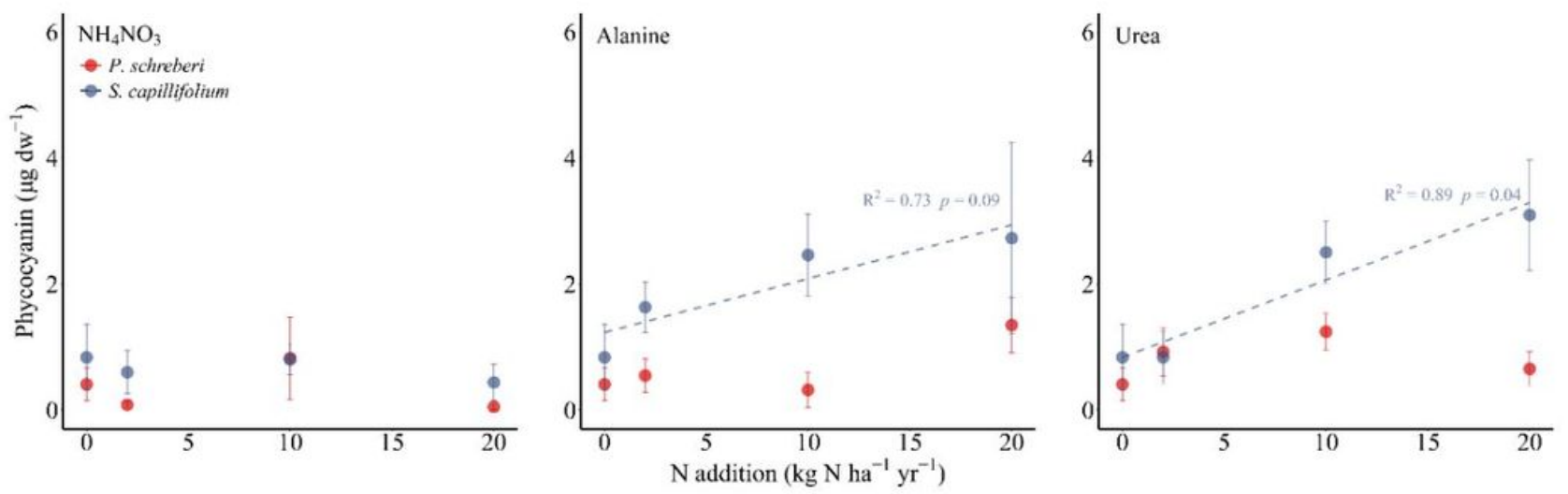

\section{Figure 5}

Phycocyanin content ( $\mu \mathrm{g} \mathrm{dw}-1)$ in moss samples in response to different $\mathrm{N}$ addition rates and forms in two moss species (P. schreberi, S. capillifolium). Given are means $\pm S E(n=6)$. Solid lines indicated the significant relationships at $p<0.05$, while dotted lines indicated the relationships at $p<0.1$.

\section{Supplementary Files}

This is a list of supplementary files associated with this preprint. Click to download.

- table.pdf

- supplement.docx 